\title{
Economic Relations between the European Union and Peru: Analysis of the Free Trade Agreement
}

\author{
Antonio Manrique de Luna Barrios
}

\begin{abstract}
After a long time of negotiation and preparation, the Free Trade Agreement between Peru and the European Union finally entered into force on the 1st of March 2013. This Free Trade Agreement will bring changes, challenges and new opportunities for the European Union and Peru. Peru will have access to the European market and the European Union can count on a new strategic partner in Latin America in terms of business relations. The Free Trade Agreement will help both parties strengthen their economic importance and position in the global scenario.
\end{abstract}

Keywords: Free Trade Agreement, Andean Community of Nations, European Union, Investments, Peru

\section{INTRODUCTION}

In the international scenario, states can live in autarky and have to interact with other members of international society. In this context the European Union has taken the decision to sign free trade agreements with different countries of Latin America with the aim of entering new markets and obtaining a better position.

The premise from which we start the present investigation is the constant relationship between states, allowing the establishment of different agreements with the objective of interchanging goods and services in a liberal way.

It is the objective of this investigation to analyze the contribution of the free trade agreement between Peru and the European Union to their economic growth. For this reason the antecedents of the free trade agreement, the negotiations between Peru and the EU to establish an agreement of association and the economic aspects of this agreement will be analyzed.

The methodology of this article is based on a multidisciplinary approach whereby economic, social and judicial aspects are regarded.

Antonio Manrique de Luna Barrios, Prof. Dr., International Public Law and International Organizations, Law Faculty, Deusto University. E-mail: a.mdel@deusto.es (Received: 05.05.2014; revision received: 03.06.2014; accepted: 12.06.2014) 


\section{ANTECEDENTS OF THE FREE TRADE AGREEMENT BETWEEN PERU AND THE EU}

The antecedents of this free trade agreement can be found in the negotiations that took place between the European Union and Andean Community of Nations (ACN) ${ }^{1}$ which wanted to establish an agreement of complete association within the following three areas: the establishment of flowing political dialogue, the creation of an area of free trade between both areas that would be favorable for free trade, investments, etc., and the formation of an intense cooperation between the countries of the Andean Community.

From this perspective it can be said that this agreement presented an important possibility for the countries of the Andean Community considering the chances that come with being associated with the European Union from a commercial point of view. ${ }^{2}$ From a political point of view and in regard to the cooperation between both regions, the relations between both regions had been built up in a successful way for a long time. And then, since the European Union was trying to establish itself as a major actor in international society it saw a great challenge and opportunity in this agreement. However, the special situation of Bolivia and Ecuador had to be considered, a situation that made necessary the establishment of a special treaty and differentiation with respect to these two countries which finally did not participate in the agreement, as we will see later.

In this context it has to be mentioned that the commercial relations between the EU and member states of the Andean Community of Nations (among which is Peru) go back to 1990 when the EU established a Generalized System of Preferences called GSP with the objective of fighting against the production and trafficking of drugs ${ }^{3}$ that was also trying to show a compromise by the developed countries in sharing responsibility with the countries throughout the process of development. To approach this transnational problem, which does not know frontiers, the EU was looking for a method of showing a politics of shared responsibility to confront this problem which is affecting the International Society.

Later, this regimen was replaced in 2005 by the Generalized System of Preferences Plus $^{4}$ which was aimed at promoting sustainable development and a regulatory policy. In regard to this we must say that custom duty preferences that were given to products coming from Member States of the Andean Community of Nations were temporary and did not include all products, making a renovation necessary in 2009.

1 The Andean Community was founded with the Protocol of Trujillo on the 10th of March 1996 as a substitute of the Andean Pact. The members of the Andean Community at the moment are Bolivia, Colombia, Ecuador and Peru. On the 22nd of April 2006, Venezuela left the Andean Community of Nations (ACN). Previously in 2006 it had announced its getting out but it had to wait five years to leave behind all its obligations and rights linked to the regional Andean group. In 2006 it also decided to enter into the Common Market of the South (MERCOSUR).

${ }^{2}$ In the area of trade the European Union had applied - in regard to the member states of the Andean Community of Nations - a general system of preferences which were renewed in 2006 and 2009 and from which the negotiations between both blocs could start.

3 The European Community was the first to establish the Generalized System of Preferences in 1971 with the objective of conceding unilaterally custom duty preferences for the products of countries which mostly need them.

4 The GSP Plus was established with the Regulation of the Council of the European Union (EC) No 980/2005 from the 7th of June 2005. 
Regardless of the criticism that could be related to the temporary character of these customs duty preferences for products from member states of the Andean Community of Nations, it has to be said that it was a successful experience since it allowed external investments to reach these countries which were trying to benefit from these preferences by introducing their products to the market of the EU.

We have to indicate that the European Parliament and Council of the European Union approved Regulation (EU) No 978/2012 on the application of the new generalized system of customs duty preferences, which repealed Council Regulation (EC) No 732/2008. ${ }^{5}$

The negotiations of the Andean Community of Nations were established based on Decision 598 which established that Member States could negotiate commercial agreements with third countries in a common way or in bloc and exceptionally by themselves on their own $^{6}$. This way an attempt was made to obtain a better position for negotiations regarding third countries and blocs of countries and to use these agreements as instruments that continue to deepen the integration and level of economic development between members of the Andean Community of Nations.

So, according to Decision 667 of the Andean Community of Nations a general framework was established for negotiations between the respective trade blocs of the EU and ACN. ${ }^{7}$

Thanks to this norm and especially that being declared in Article 2 of this norm, Colombia and Peru were able to advance in bilateral negotiations with the EU specifically in case any difficulties were to occur in the regular negotiations between trade blocs; in case, for example one of the other ACN members (for example Ecuador or Bolivia) decided to leave the trade bloc negotiations. This way Peru and Colombia could continue their negotiations with the EU

Clearly it was required that Peru and Colombia respect the community law of the ACN considering the sensibilities of the other Member States of the Andean Community of Nations and the existence of transparency, information and solidarity was also needed during the process of negotiation. These dispositions aimed to achieve the goal of Bolivia and Ecuador not leaving the negotiations. Both countries were critical candidates concerning the negotiation process and preferred to participate in another free trade agreement the so called "Bolivarian Alliance for the Peoples of Our America - Peoples' Trade Treaty".

Like it was said before, the commercial relations resulting from the signing of this agreement of association planted an important challenge for Latin America, which had started to enter into a phase of more economic development and social integration, and a European Union trying to establish more important economic relations with this bloc that

5 The new scheme approved by Regulation 978/2012 entered into force on the 20th of November 2012 and the custom duty preferences granted with this new order were applicable from the 1st of January 2014. In regard to the actual scheme GSP Plus would only be applicable from the 31st of December 2013, according to Regulation N ${ }^{\circ}$ 512/2011.

${ }^{6}$ Decision 598 from the Andean Council of Ministers of Foreign Affairs together with the Commission of the Andean Community, which regulates the commercial relations with third countries was approved on the 11th of July 2004.

7 Decision 667 called general frame for negotiations of the Agreement of Association between the Andean Community and the European Union was adopted on the 8th of June 2007. Later, since a negotiation by blocs was not possible, Member States of the ACN were allowed to carry out bilateral negotiations with third countries and for this it was necessary to abrogate Decision 667 with Decision 738 from the 1st of July 2010. 
had shown progress in the area of law, economics and social aspects (Vid. Stiglitz-Charlton 2007). It seems that after the signing of the agreements with Mexico and Chile there had come the moment to give an interesting position to the Nations of Latin America and face new challenges (Sotillo Lorenzo 2000).

During 2006 a number of meetings took place between the representatives of the Andean Community of Nations and European Union that led to the fact that on the 14th of July of 2007 the beginning of negotiations about the agreement of association between the European Union and its Member States and the Andean Community of Nations and its Member States started.

With regard to the European Union it has to be mentioned that during this process of negotiation it always tried to establish discussions between blocs and for this reason it was necessary to follow a type of politics that fostered a common Andean market. ${ }^{8}$ Unfortunately the negotiations between blocs did not reach a conclusion, nor result in the creation of a common Andean market which had to concede positions considering the almost completely free trade that some Member States (especially Peru) had developed and established with respect to other countries.

All these antecedents and the fact that certain facilities had been given to the member states of the ACN so that they could assume their compromises in different time frames, meant that - as a result of the differing velocities and dependency on their own situations it was complicated and difficult for the blocs to negotiate. Also the Customs Union of the ACN could not consolidate itself within the framework of the ACN since the Member States of this organization did not find a common point of agreement between their political agenda. Finally, in June 2008 the negotiations between the blocs failed.

It has to be mentioned that the negotiations between blocs were probably affected a lot because of the participation of Ecuador and Bolivia in the ALBA-TPC ${ }^{9}$ given the fact that these countries considered this negotiation as not being aimed at developing the cooperation and political dialogue as much but rather putting more priority on the commercial area which was an excuse to promote a simple free trade agreement (Vid. Gómez Galán 2001). Later, within the framework of the European Union the possibility was established to start and carry out negotiations with only Peru and Colombia since it had been impossible within the framework of the Andean Community of Nations to reach a consensus, and topics such as trade, sustainable development and intellectual property had not been universally focused by the Member States of the ACN.

\section{THE NEGOTIATIONS BETWEEN PERU AND THE EUROPEAN UNION TO ESTABLISH AN AGREEMENT OF ASSOCIATION}

With regard to the bloc that existed during the negotiations of the Agreement of Association, it was necessary to ask the European Union for certain new conditions to reinvent and redesign the initial scheme of negotiations including the participation of Peru, Colombia and Ecuador. Later, in July 2009 Ecuador ended its participation in these negotiations.

8 The EU had signed Free Trade Agreements with: Turkey, Egypt, Morocco, Israel, Jordan, South Korea, Chile, Mexico, etc.

9 The Bolivian Alliance for the People of our America - People`s Trade Agreement (ALBATCP) was established on the 14th of December 2004. 
This new negotiation tried to stay within the regulations of Article XXIV of GATT and Article V of GATS ${ }^{10}$ that had been established within the framework of the World Trade Organization. This way the negotiations were reestablished in areas such as the rule of origin, the technical barriers of trade, trade and sustainable development, etc. Later, after a new series of negotiations (the last one having taken place in February 2010 in Brussels), the end of the negotiations in April 2011 was officially announced and it was established that the agreement would be controlled by the legal procedures of each one of the participating parties.

On the 31st of May 2012 the Council of the European Union approved the provisional signature and application of the Trade Agreement between Peru and the EU (this agreement was also approved with regard to Colombia) ${ }^{11}$. Later, on the 26 of June 2012 the agreement was signed and submitted to the European Parliament as well as the Congress of Peru for approval according to the European and Peruvian regulations. However, it was necessary to obtain the approval of the national parliaments of Member States of the EU since the agreement contained regulations concerning intellectual property, among other aspects.

With regard to the procedure it has to be said that the EU, more specifically the European Parliament, approved the Trade Agreement (11th of December 2012) ${ }^{12}$ with a majority and the Congress of Peru approved it the following day unanimously. Considering the procedure concerning the signing of the Free Trade Agreement between the EU and Peru it has to be mentioned that earlier it was able to be approved by the plenum of the European Parliament. In the case that the Commission of International Trade of the European Parliament had not approved the agreement, there would have existed other procedural options to put the issue to the agenda of the plenum of the European Parliament ${ }^{13}$.

In terms of the content of the Treaty it should be indicated that a chapter was established which has been designated to sustainable development and the consideration of aspects which respect the main international regulations in areas such as labor conditions and environment. Also, certain social aspects have been regarded in respect of questions that Civil Society should ask, and the establishment of a clause of human rights has also been recognized that allows the immediate suspension of the treaty in case of a violation but at the same time certain power has been granted to diplomatic means and mechanisms that can be established between the parties to solve any controversy ${ }^{14}$.

10 The Free Trade Agreement that Peru finally signed with the EU established a compromise assumed by Peru with regard to the liberalization of the sector of services that goes further beyond that being established in GATS; for example, in the sector of maritime and aerial transport. On the other hand the European Union has given preferential access to its market to all providers of contract and independent professional services of Peruvian origin.

11 European Union, Council Decision 2012/735/EU of 31 May. Official Journal of the European Union L354 (Volume 55) of 21 December 2012.

12 The European Parliament approved the Free Trade Agreement with Peru with 486 votes in favour, 147 against and 41 abstentions.

13 The Commission of International Trade of the European Parliament approved the Treaty between Peru and the EU with majority. The result of the voting was 20 votes in favour, 4 against and 1 abstention.

14 The aspects with regard to a democratic clause, the respect for both human rights and the state of law that were established in the Agreement of Political Dialogue and Cooperation, which was signed in 2003 between the EU and can, have been incorporated into the Free Trade Agreement between Peru and the EU. 
Continuing we are going to present a short review of the main aspects established by the free trade agreement between the EU and Peru.

As it was said before the treaty in question was initially formulated over a number of negotiations that were carried out in three rounds between the EU and Andean Community of Nations (negotiations from bloc to bloc) which later were re-thought and resulted in new negotiations between the EU on one side and Peru and Colombia on the other side. Unlike the failed negotiations from trade bloc to trade bloc these ones were successful and came to an end in nine rounds.

Regarding the content of the Free Trade Agreement between the EU and Peru it can be said that it is structured the following way: Preamble, fourteen titles, fourteen annexes and two conjoint declarations.

This way in the first two titles a number of initial and institutional regulations have been established. Also, the trade of goods has been regulated ${ }^{15}$ (third title), as has the trade of services, establishments and electronic trade (fourth title), payments and movement of capital (fifth title), public contracting (sixth title), ${ }^{16}$ intellectual property ${ }^{17}$ (seventh title), competition (eighth title), trade and sustainable development (ninth title), the transparency and administrative procedures (tenth title), the general exceptions (eleventh title), the solution of controversies (twelfth title), the technical assistance and the strengthening of commercial capacities (thirteenth title) and the final regulations (fourteenth title). ${ }^{18}$

15 Among the regulations that regulate the trade of goods a number of norms have been established that eliminate custom duties and create a means of banishing custom duties (technical barriers to trade), the management of administrative errors, etc. In this sense the possibility has been established to ask for technical assistance from the EU in case there should be a surge in any difficulty with regard to the application of technical regulations of the EU.

${ }_{16}$ Peruvian companies can participate in any public tender in any state of the EU with the same conditions as any other potential investor of the EU.

17 Title VII of the Free Trade Agreement regulates the protection of biodiversity and traditional know-how, geographical indications, patents, unfair competence, etc. I would like to add, that in a country like Peru which has great biological diversity and variety of traditional knowledge it is important as to what has been regulated in the Seventh Title of the Agreement in regard to intellectual property in relation to the traditional knowledge. According to the Convention about biological diversity in its Article 8 it regulates that the term traditional knowledge is used for know-how, innovations and practices of the Native and local communities that have traditional ways of life, where there is an interest in conserving them and a sustainable use of biologic diversity shall be made. However, there is no clear norm to protect the intellectual property of ancient know-how. In Article 201 paragraph 6 of the Agreement the participating parts have agreed to cooperate "to assure the intellectual property rights help and are not opposed" to the rights of Native and local communities, but with "dependence on the national legislation". This expression makes reference to national rights and can be a risk. For example, when a state member of the EU allows the ancient know-how that someone has learned during a journey in Peru to be registered as belonging to a national of the EU. However in such cases, by mutual agreement it has been regulated in Article 201 paragraph 30 the will to respect, conserve and maintain innovations, knowledge and practices of Native and local communities.

18 According to the Preamble of the Free Trade Agreement the participating parties try to promote an integral economic development with the objective of reducing poverty and creating new opportunities for jobs and better conditions for work with the liberalization and expansion of trade and investment in their territories. In Title I the respect for democratic principles and fundamental rights has been declared. Also a zone of free trade has been created and it has been established that all 


\section{ECONOMIC EVALUATION OF THE AGREEMENT BETWEEN THE EU AND PERU}

The commercial agreement between Peru and the EU has generated an opportunity to participate in a clear way in a consolidated market as it is the European market, and not lose competitiveness in regard to other countries with which the EU has signed free trade agreements (Vid. Bolaky, Bineswaree y Caroline Freund 2006), However, there exist a number of socio-economic aspects that will result from the signing of the treaty and that will be analyzed in the continuation.

The commercial agreement that Peru has signed with the EU will make it easier for Peruvian products to access the market of the European Union in which more than 500 million people are integrated. With the independence of the other 16 Free Trade agreements that Peru has signed with other countries the number of potential consumers has the greatest economic impact so far. However, we should not forget that during the negotiations of the European Commission and Peru the two towers of the Agreement of Association were left aside that made reference to political dialogue and to a cooperation that should be concreted in a free trade agreement which would permit the liberalization of services, public tenders and investments, etc.

The Treaty gives permanent, reliable and predictable preferential access to Peruvian products concerning the common European market and allows the introduction into this market of a number of goods and services. The new agreement offers Peruvian products

parts consider the dispositions of the WTO. In Title II a Committee of Trade has been established which is composed of representatives of the EU and Peru. Also a number of subcommittees have been established as well as a Coordinator of Agreement that represents all parties.

In Title III it is defined that the parties will liberate their trade of goods in a gradual way and in concordance with article XXIV of GATT from 1994. Title IV establishes norms to facilitate the economic integration, sustainable development and continuous integration in the global economy. And considering the differences in the level of development between the parties it establishes the necessary dispositions for a progressive liberalization of trade with services and for the cooperation in topics such as electronic commerce.

In Title V privacy protection is regulated and in Title VI general principles are established in regard to public contraction, offers and the adjudication of contracts.

Title VII regulates intellectual property, national treatment and preferential treatment. In Title VIII the policy of competence is regarded as well as the authorities that control a free interchange. Title IX contemplates trade and sustainable development and establishes certain norms to protect the environment.

Title X of the Free Trade Agreement wants to mark transparency and administrative procedures and has the objective of protecting confidential information. In Title XI it is declared that neither disposition of the Free Trade Agreement can be interpreted in a way that might give access to information which in the case of divulgation could harm essential security interests of the parties or could avoid one party taking means to protect essential interests in regard to security. In Title XII arbitrary procedures can be found to solve controversies that arise with the interpretation and application of this agreement. Finally, in Title XIII a number of mechanisms have been established to offer technical assistance with the objective of increasing sustainable economic development and reducing poverty. In Title XIV there are the final dispositions. 
more advantages than GSP Plus. ${ }^{19}$ Additionally it will permit a progressive liberalization of the commerce of services.

When the agreement came into force (February 2013) there was a specific tariff reduction of $100 \%$ for non-agricultural products and $75.9 \%$ for agricultural products given the importance and sensibility of this topic in this sector within the European Union - averaging an overall tariff reduction of $99.3 \%$.

On the other hand, the EU has the opportunity to export manufactured goods and products to the Peruvian market and invest capital which allows European providers to keep selling their products and compensates them for decreasing sales in the European market during the economic crisis by which Europe has been affected. ${ }^{20}$ Considering the situation at the moment, the EU has been able to benefit from the free trade agreement since its investors had the possibility of investing in an interesting destination with great potential. For example, the banking system originating in Europe (especially the Spanish banking sector) has established itself in Latin America and especially in Peru and has completed a successful year with great results and in a certain way this has helped compensate for the lacking dynamics of the European market.

This way manufactured goods and European capital have entered into a country which in 2013 had a growth rate of $5.0 \%,{ }^{21}$ prospered constantly and saw the purchasing capacity of its population increase. These are important factors for deciding whether a destination is an adequate place for European products or not and a destination for investments abroad.

With regard to the regulations of the agreement it can be mentioned that exports have increased and more products are offered (Vid. Agosín 2009). The majority of exports from Peru into the EU market are agricultural products. ${ }^{22}$ This has resulted in the fact that lifestyle conditions for thousands of Peruvian families have improved and they have seen this new export destination improving their conditions and resulting in extreme states of poverty - that this country had been confronted with in the past - being left behind. However, the export of oil and gas has risen as well at a constant level since 2010.

The commercial agreement between the EU and Peru will contribute to improve the lifestyle level of Peruvian citizens since they will be able to sell their products in the European Union more easily. This way, for example we can say that between 2008 and

19 The agricultural products have a progressive and partial liberalization of between 85 and 90\% of the products in Peru and also in the EU. On the other hand industrial products and Peruvian fish are free and can enter into the European market since the entering into force of the treaty.

${ }^{20}$ We should consider that the President of the United States wants to increase the exports of small and medium sized companies from the U.S. to the Latin American market because these exports mean about four million employment positions for citizens of the United States. Also, he is trying to conquer the market of services. It might be that the European Union has become aware of this new political agenda of the U.S.A. towards this region and that due to the constant progress has decided to follow the model of the U.S. that has proven to be successful. Before the free trade agreement was signed between the EU and Peru, the second one implemented a free trade agreement with the United States on the 1st of February 2009. Vid. Presidential Proclamation 8341 - To Implement the United States-Peru Trade Promotion Agreement and for other Purposes.

21 Vid. Instituto Nacional de Estadística e Informática del Perú "National Institute of Statistics and Informatics of Peru” (INEI). In: www.inei.gob.pe

22 The EU has kept its subventions for the agricultural producers due to their great importance in the EU, but obviously this practice generates an unfair competence. Also in the area of lacteal products there is a certain advantage given to milk in powder form coming from the EU compared to fresh milk which cannot compete with the respective range of prices. 
2012 the trade balance between the European Union and Peru has been favorable for Peru and this situation is suspected to continue into the future due to the liberalization of custom duties presented by this treaty.

However, to assure a continuing growth it might be important to establish a system that promotes the creation of cooperatives and mechanisms; facilitating access to credits and financing for the Peruvian people -so that they have a better capacity to respond to the changing demand for products that come from the market in Europe - and development of their skills and capacity in management and business administration. For example, in Peru there are cooperatives for savings and credits - they are businesses of joint property and are managed in an autonomous way and it is their objective to attend the needs of their members and partners. ${ }^{23}$ We think that the cooperatives are a powerful instrument that can help Peruvian producers organize and finance themselves as well as their activities and explore another alternative to the traditional financial system.

It has to be considered that Micro and Small Businesses (MSB) ${ }^{24}$ might also be affected by the Free Trade Agreement between the EU and Peru since Peruvian industries see themselves replaced by European companies. This way, for example the Peruvian paper and leather industries that offer great quality and are of great importance to the Peruvian

23 More information about the cooperatives in Peru can be found in "Texto Único Ordenado de la Ley General de Cooperativas" which was approved by the "Decreto Supremo No. 074-90-TR" from the 14th of December 1990.

24 According to the recommendation of the European Commission from the 6th of May 2003, based on the Charter of Small Companies emitted from the Council of Europe from Santa Maria da Feira in June 2000, which came into force on the 1st of January 2005, a small company is an economic union with juridical or physical personality which has less than 10 employees and an annual volume of business or general annual balance of less than 2 million euros, expenses of less than two millions euros and a balance of 2 million euros or less. Vid. European Commission Recommendation 2003/361/ CE, 6 of March 2003 about the definition of micro, small and medium-sized businesses. Within the European Union a "Small Business Act" was also adopted which is a non-binding instrument for the Member States of the EU to commit themselves to take actions to help and support small businesses. The SBA suggests the following strategy of action: education and formation to promote a spirit of entrepreneurship, and the reduction of costs for the creation of businesses. Another objective is to facilitate legislation, give adequate training adapted to the needs of small companies and improve the relationship between administration and businesses by using new technologies. Also the opportunities of the internal market shall be improved, tax and financing, promotion for the new technologies of small companies, support for the globalization of small companies in the new economy. Also the potential and effectiveness of the representation of interests of small companies at a national level and a European Union level shall be improved. Vid. Communication from the Commission to the Council, the European Parliament, the European Economic and Social Committee and the Committee of the Regions. Com(2008)394 final "Small Business Act" of 26 June 2008. On the other hand the micro company has been regulated in Peru with the "Texto Único Ordenado" of the "Ley de Promoción de la Competitividad, Formalización y Desarrollo de la Micro y Pequeña Empresa" and the "Acceso al Empleo Decente, Ley MYPE (Decreto Supremo No.007-2008-TR)”. In this regulation a MASC is defined as an economic union constituted by a natural or juridical, founded with any type of organization or management structure and considered in the valid legislation. It has to have as an object the development of activities of extraction, transformation, production, commercialisation of goods or the provision of services and it should combine two characteristics: the number of employees should not be more than 10 and the amount of maximum sales per year should be 150 UIT (Tax Unit). 
market could be affected; specifically, a substitution of Peruvian products for European products could occur. $^{25}$

Peru needs to improve its business connections and has to strengthen its production circles internally to gain productivity and competitiveness - this way a better distribution of riches can be achieved that enter into the country. At the same time Peru should strengthen its relations with Bolivia and Ecuador (both members of the Andean Community of Nations which did not come to finalize the negotiations with the European Union and for which reason the negotiations of the Agreement of Association between the blocs stopped) because after this process a number of tensions affected the process of integration of the Andean region in a certain way. The process of integration, however, is a process that Peru should not leave aside because of the commercial contacts that it implies and the better position in terms of negotiations that its cooperation would mean in the international scenario. ${ }^{26}$

The commercial agreement also allows the counting in clear and precise norms of trade in goods, services and investments. This way certain levels of insecurity can be avoided that can create fears and hinder investments in countries such as Peru ${ }^{27}$. The fact that the necessary mechanisms have been established to solve any commercial controversy that could arise with the application of the agreements is also a great incentive for investments in the country. However, some doubts have arisen with respect to the importance that has been given to a political solution between the parties or the recommendation that a group of experts could give when labor laws are not respected.

Regarding direct foreign investment into Peru, it can be said that $51.6 \%$ comes from the European Union and United Kingdom. The main sectors where specific foreign investments are carried out are: trade, communication, energy, finance, industry, mining, petroleum, services, transport, agriculture, construction, fishing, etc. The communication sector is the most dynamic at the moment and capital has been canalized there from Spain, the U.K. and Holland.

Also it should be considered that the contribution to increasing and improving the grade of industrialization and modernization of Peruvian companies will make it easier for these companies to enter the European market. At the same time European companies should be able to gain experience in a new market with a great potential. By getting to know the different tastes and preferences of Latin American consumers, European companies could use Peru as a platform for future investments in the region. In addition

25 European Commission (2009) Evaluation of the impact about the sustainability of the trade between the EU and the Andean countries. In: http://trade.ec.europa.eu/ doclib/docs/2010/april/ tradoc_146016.pdf

${ }^{26}$ General Secretary of the Andean Community (2013). Dimensión Económica Comercial de la Comunidad Andina. Publicaciones CAN.

27 However, considering the initial fear about investing in this country, it has to be mentioned that Peru has developed a normative framework to protect investments from abroad and has shown a great interest with regard to the international legal order. So, for example, in the Constitution it is worth pointing out article 70 (that guarantees the invulnerability of private property), article 58 (that regulates the private initiative within the framework of a market of a social economy), article 59 (that guarantees the liberty of companies by the State), article 62 (that guarantees the liberty of contracting), and other regulations. We should also mention the following norms as a guarantee for the investments: The "Ley Marco" for the growth of private investment, The Constitutive Agreement of the Multilateral Investment Guarantee Agency (MIGA) of the World Bank, The ICSID Convention of the International Centre for Settlement of Investment Disputes (ICSID), among other dispositions. 
there exists a great opportunity to establish cooperation between Peruvian and European companies.

Obviously with this agreement there is the risk that Peruvian companies do not have the capacity to modernize their operability according to the new requirements and lose their creative side that has always characterized them. The fact that in Peru the salaries are very low can be a factor to attract European companies that are trying to establish themselves in this country. But at the same time this can present a risk for the European economy where - due to the crisis - unemployment is a complicated problem to solve. However, it is always important that labor laws are respected, as well as environmental laws, and civil society is consulted and not left aside (especially in respect of Native people) because a situation of social exclusion could affect important sectors of society (people that live in extreme poverty, Native people, women, etc.)

\section{CONCLUSION}

The existence of the Free Trade Agreement between the European Union and Peru which entered into force on the 1st of March 2013 will not generate by itself a major flow of trade and investment. It will simply generate a number of opportunities and at the same time potentially present dangers for Peruvian companies.

For this reason, it is fundamental that Peru develops strategies that makes itself less vulnerable in respect of those aspects that still have to be developed (for example innovation and development, education, infrastructure, etc.); continues to gain major experience and competitiveness that allows itself to export its products to the EU; and positions itself against products coming from third countries that enter the country as well.

The key can be found in the capacity of the Peruvian economy to control the problems that are generated by the application of the agreement with regard to those products that have a greater sensibility and should have been protected during the process of negotiation with the mechanisms of commercial defense. Also, it should profit from the advantages that result from this agreement with a clear political agenda to increase its competitiveness with an industrial or business reconversion towards more important sectors - and constant cooperation with the private national sector.

Peru should not lose the opportunity to interact in a market that is so important and not concentrate on being merely an exporter of primary materials (mainly combustibles and mining products). Since it is a country which carries out exports of high value it should, with an adequate political strategy in the private sector and adequate interaction with the private sector, try to invest and improve the sectors that need to be most developed. We should not forget that the third most important providers of machines and equipment for transportation in Peru come from the EU, elements that are indispensable for the industrial development of Peru and a requirement for it to continue to grow and be able to carry out exports with higher value.

How well the products of a country enter into different markets depends on the countries, their institutions and their companies. Constant issues such as competition have to be discussed at all levels and there has to be investment in the industrial and technological development of the country.

On the other hand the European Union has found a partner that is from an economic point of view one of the most stable countries in the Latin American region that continues to grow constantly and has taken the opportunity to establish a cooperation between the 
European Union and Peru which contributes to benefit both parties and promotes competition, innovation, the transfer of technology, the modernization of industry, etc.

This agreement presents an opportunity to promote European interests and defend its values. It also is an opportunity to continue strengthening international free trade with established norms. Also norms and values that can be found in the European Community can be promoted and made an important part of free trade.

With the Free Trade Agreement with Peru, the EU will be able to enter with its investments into the Peruvian market freely and with a national treatment (it should not be forgotten that more than $50 \%$ of direct foreign investment in Peru comes from the EU and the EU is the major investor in this country). However, Peru has maintained with the regulations of the Treaty certain horizontal liberations in all sectors that allow it to take means so that less favored minorities or ethnic groups can be protected when it is deemed necessary. The Free Trade Agreement between Peru and the EU has not established norms to protect investments nor it has established mechanisms to solve controversies between investors and the state which have been left under the "protection" of the bilateral treaties of investment that were signed by both parties and continue being in force.

\section{REFERENCES}

Agosín, M. (2009): “Crecimiento y diversificación de exportaciones en economías emergentes”, Revista CEPAL, № 97.

Bolaky, Bineswaree y Caroline Freund (2006): “Trade, regulations, and growth”. International Monetary Fund. Washington, D.C.

Gómez Galán, M. (2001): La cooperación al desarrollo en un mundo en cambio. Madrid: Centro de Comunicación, Investigación y Documentación Europa - América Latina (CIDEAL).

Sotillo L. J. (2000): Las relaciones Unión Europea - América Latina: el cambio del olvido a la asociación. Madrid: Editorial Tecnos.

Stiglitz, J.-Charlton, A. (2007): Fair Trade for All: How Trade Can Promote Development. New York: Oxford University Press.

\section{NORMS}

Andean Community, Protocol from Trujillo 10 March 1996.

Andean Council of Foreign Ministers and the Commission of the Andean Community, Decision 598 of 12 July 2004, "Trade relations with third countries."

Andean Council of Foreign Ministers and the Commission of the Andean Community, Decision 667 of 8 June 2007, "General framework for the negotiation of the Association Agreement between the Andean Community and the European Union."

Andean Council of Foreign Ministers and the Commission of the Andean Community, Decision.

Commission Recommendation 2003/361/EC of 6 May 2003.

Communication from the Commission to the Council, the European Parliament, the European Economic and Social Committee and the Committee of the Regions. Com(2008)394 final "Small Business Act” of 26 June 2008.

Convention on Biological Diversity (CBD) of 5 June 1992.

Convention on the Settlement of Investment Disputes between States and Nationals of Other States International Centre for Settlement of Investment Disputes, 18 March 1965.

Council Regulation (EC) No. 980/2005 of 27 June 2005.

Council Regulation (EC) No. 732/2008 of 22 July 2008.

European Commission (2009) Evaluación del Impacto sobre la sostenibilidad del comercio entre la UE y los Países Andinos. En: http://trade.ec.europa.eu/ doclib/docs/2010/april/tradoc_146016.pdf

European Council, European Charter of Small Companies Emitted from the European Council of Santa Maria da Feira from 19 -20 June of 2000. 
European Union, Council Decision 2012/735/EU of 31 May. Official Journal of the European Union L354 (Volume 55) of 21 December 2012.

General Agreement on Trade in Services (GATS).

General Agreement on Tariffs and Trade (GATT).

Ley Marco para el Crecimiento de la Inversión Privada. Decreto Legislativo 7578 of November 1991.

Presidential Proclamation 8341 - To Implement the United States-Peru Trade Promotion Agreement and for other Purposes.

Regulation (EU) No. 512/2011 of the European Parliament and of the Council of 11 May 2011.

Regulation (EU) No. 978/2012 of the European Parliament and of the Council of 25 October 2012.

Secretaría General de la Comunidad Andina (2013). Dimensión Económica Comercial de la Comunidad Andina. Publicaciones CAN.

Texto Único Ordenado de la Ley General de Cooperativas. Decreto Supremo No. 074-90-TR of 14 December of 1990.

Texto Único Ordenado de la Ley de Promoción de la Competitividad, Formalización y Desarrollo de la Micro y Pequeña Empresa y del Acceso al Empleo Decente. Decreto Supremo No.007-2008TR of the 30 September of 2008. 